\title{
ARCABOUÇO E EVOLUÇÃO ESTRUTURAL DO ARCO DE PONTA GROSSA NO GRUPO SÃO BENTO (MESOZÓICO): IMPLICAÇÕES NA HIDRODINÂMICA DO SISTEMA AQÜÍFERO GUARANI E NA MIGRAÇÃO DE HIDROCARBONETOS NA BACIA DO PARANÁ
}

\author{
MICHAEL STRUGALE
}

\author{
DISSERTAÇÃO DE MESTRADO - Programa de Pós-Graduação em Geologia - UFPR \\ DATA DE DEFESA: 29 nov. 02
}

\begin{abstract}
O presente trabalho teve como objeto de estudo as estruturas tectônicas presentes nas rochas do Grupo São Bento (Mesozóico da Bacia do Paraná), mais especificamente onde a faixa aflorante dos quartzo-arenitos das Formações Pirambóia e Botucatu é secionada pelo Arco de Ponta Grossa, região centro-norte do estado do Paraná. Análises estruturais descritiva, cinemática e dinâmica foram utilizadas na interpretação dos dados fotogeológicos, de campo e modelos digitais de terreno. O Arco de Ponta Grossa, uma das mais proeminentes estruturas da Bacia do Paraná, promove intensa segmentação tectônica das rochas da bacia e é acompanhado por um dos mais expressivos enxames de diques do planeta. O mesozóico é a principal época de atividade do arco, o qual apresenta estreita relação com os magmáticos e epirogenéticos que levaram à abertura do Oceano Atlântico Sul, cujos reflexos na bacia são, além do próprio arco, os magmatitos intrusivos e extrusivos juro-cretáceos da Formação Serra Geral (Grupo São Bento). Compreender o arcabouço, evolução, compartimentação estrutural e Morfoestrutural da área define o objetivo central da pesquisa. Como objetivos conseqüentes deste, temos: 1) compreender a influência do arcabouço estrutural na hidrodinâmica do Sistema Aqüífero Guarani (um dos maiores do mundo), cujas rochas-reservatório são representadas pelas Formações Pirambóia e Botucatu; 2) implicações da evolução estrutural na migração de hidrocarbonetos no Sistema Petrolífero I-RB/P (Irati - Rio Bonito/Pirambóia), visto que as deformações estudadas são contemporâneas aos momentos críticos deste sistema petrolífero. Contíguo aos
\end{abstract}

objetivos supracitados, a presença de uma diversidade de estruturas tectônicas penecontemporâneas na Formação Rio do Rasto (Grupo Passa Dois - Permiano Superior) motivou a descrição e interpretação expedita das mesmas. São relacionadas ao evento orogenético de colisão do Bloco da Patagônia com a Plataforma sulamericana, no intervalo Neo-Permiano a Neo-Triássico (Orogenia Sanrafaélica). A área de estudo apresenta-se compartimentada por dois conjuntos de estruturas tectônicas principais, N40-55W e N40-60E (secundária), além de feições esparsas de direção E-W e N-S. Dois eventos tectônicos (D1 e D2) foram responsáveis pela geração e reativação das estruturas rúpteis das rochas do Grupo São Bento na área: D1) atuou no Eo-Cretáceo e apresenta regime tectônico predominantemente extensional, com componente direcional dextral nas faIhas noroeste; responsável pela colocação dos diques; D2) compreende a maior quantidade de fraturas observadas nos afloramentos, deformação nos arenitos. Apresenta regime transtensional e o $\mathrm{SH}_{\text {máx }}$ varia entre NE-SW e ESE-WNW, com intervalo de atuação do Neo-Cretáceo ao Terciário. O arcabouço estrutural do Arco de Ponta Grossa promove inflexões e compartimentações nas curvas potenciométricas do SAG, que somadas ao condicionante regional do fluxo, controlado pelo merguIho regional das camadas, condiciona a hidrodinâmica do aqüífero. Os eventos tectônicos D1 e D2 promovem dois momentos de formação/destruição de trapas estruturais, que por sua vez condicionam pulsos de migração de hidrocarbonetos através das falhas enquanto estas apresentam-se ativas. 